\title{
Climate Change Adaptation and Mitigation Options through strengthening carbon Management in Central Africa: Biomass allometric models of Khaya senegalensis (Desr.) A. Juss (meliaceae) in Cameroon
}

Djongmo Victor Awé ( $\square$ awevictor20@yahoo.fr)

Universite de Ngaoundere Faculte des Sciences

Bi Tra Aimé Vroh

University of Felix Houphouet-Boigny: Universite Felix Houphouet-Boigny

Noumi Valery Noiha

Universite de Ngaoundere Faculte des Sciences

Moussa Ganamé

Joseph Ki-Zerbo University: Universite Joseph Ki-Zerbo

Djawé Yannick Wanguili

University of Maroua: Universite de Maroua

Mboudga Christelle Maïtching

Universite de Ngaoundere Faculte des Sciences

Boris Nyeck

Universite de Ngaoundere Faculte des Sciences

Louis Zapfack

University of Yaounde I: Universite de Yaounde I

\section{Research Article}

Keywords: Allometric equation, Biomass, Cameroon, Climate change, REDD+

Posted Date: August 16th, 2021

DOl: https://doi.org/10.21203/rs.3.rs-815091/v1

License: (c) (i) This work is licensed under a Creative Commons Attribution 4.0 International License.

Read Full License 


\section{Abstract}

This study focused on the development of allometric models of Khaya senegalensis in order to establish a basis for calculating carbon stocks. The research was carried out in the Adamawa, North and Far North region of Cameroon. The weighing of the samples of each part (stem, branch, leaf) of the sample of trees composed of 60 feet of Khaya senegalensis and their drying in the oven made it possible to know the dry biomass of each subject Adjusted coefficients of determination (Adj. $\mathrm{R}^{2}$ ), residual standard error (RSE) and Akaike's information criterion (AIC) were used to choose the best models. Thus, the tested models presented varied performances. The various analyzes have confirmed that the diameter at breast height $(\mathrm{DBH})$ is the variable that offers the best correlation with above-ground (AGB) and below-ground (BGB) biomass. The best selected models are: $\ln (A G B)=1.004-0.054 * \ln (D)$ and $\ln (B G B)=-3.009+0.016 * \ln$ (D) (Adamawa); $\ln (A G B)=0.004+0.054 * \ln (D)$ and $\ln (B G B)=-1.301+0.116 * \ln (D)$ (North); $\ln (A G B)=$ $0.004+1.084 * \ln (D)$ and $\ln (B G B)=-0.002+0.016 * \ln (D)$ ( Far North). The best models selected for the global equations for the three regions are: $\ln (A G B)=0.504+3.048 * \ln (D)$ and $\ln (B G B)=-0.109+0.306 * \ln$ (D). Models were proposed to estimate the carbon of Khaya senegalensis in Cameroon.

\section{Introduction}

Africa is the continent most vulnerable to the impacts of climate change (Thiam et al. 2014).Forest ecosystems play a key role in mitigating the adverse effects of climate change, by absorbing carbon dioxide, one of the main greenhouse gases greenhouses responsible for global warming (Ganame et al. 2021). Indeed, they constitute real carbon sinks, both in the vegetation and in the soil. Among forest ecosystems, tropical forests with 7\% of the world's land surface (Ganame et al. 2021), alone absorb around 40 to $50 \%$ of terrestrial carbon (Ganame et al. 2021). Estimation of biomass is an essential step in assessing the carbon stock of forest ecosystems (Goetz et al. 2015).

The biomass of forest ecosystems is generally estimated through allometric equations using the dendrometric parameters of trees as variables (Bayen et al. 2015; Chabi et al. 2016; Fayolle et al. 2018). The lack of reliable allometric equations specific to Sahelian ecosystems has led to the use of pantropical models (Chave et al. 2014), generating uncertainties in the estimation of the biomass of African forests (Djomo et al. 2010, Henry et al. 2010). Tree biomass, which includes the biomass of stems, branches, leaves and roots, is an important store of atmospheric carbon (Xue et al. 2016; Ganame et al. 2021). The abundance of a tree's above-ground biomass is an indicator of its ability to efficiently sequester atmospheric carbon through the process of photosynthesis (Dimobe et al. 2018a).As a result, several studies have focused on estimating above-ground biomass to the detriment of below-ground biomass, the assessment of which remains difficult and is not very precise (Mensah et al. 2017; Djomo \& Chimi 2017; Dimobe et al. 2018a; Balima et al. 2019). Tree biomass can be assessed either by the direct method, by the indirect method, or by remote sensing techniques. The most commonly used and most accurate method is the direct so-called destructive method (Fayolle et al. 2013). 
Efficient estimation of the biomass of forest ecosystems requires the use of precise allometric equations (Ganame et al. 2021). The development of these equations requires the collection of biomass data from standing trees by the destructive method (Djomo and Chimi 2017). However, the unavailability of accurate biomass estimation equations hinders the assessment of biomass of forest ecosystems in African countries (Henry et al. 2011) and the inclusion of these forests in climate change mitigation. The allometric models developed in African countries are limited to humid forests (Fayolle et al. 2013; Djomo and Chimi 2017). According to (Djomo and Chimi 2017), the lack of adequate mathematical models for estimating the biomass of African forest ecosystems has led to an overuse of the equations developed by Chave et al. (2014).

However, the accuracy of these global models is questionable, given that the allometric equations are closely dependent on the abiotic conditions of the sites and the structural characteristics of the species (Djomo et al. 2016). Biomass information, site and species specific, is therefore needed to improve the accuracy of biomass estimates for African forests. This results in a lack of precise information on biomass stocks hampering the assessment of the contribution of the country's forest ecosystems in the mitigation of climate change through carbon sequestration. Therefore, mathematical models must be developed to estimate the biomass of forest ecosystems in Cameroon. The resurgence of extreme climatic phenomena such as droughts and floods are manifestations of this climate change. The risks associated with this change affect every continent, and affect all socio-economic sectors of populations (Ganame et al. 2021). It is therefore urgent to identify the mechanisms for reducing the concentration of GHGs in the atmosphere. Hence the objective of this work is to develop allometric models for predicting above and belowground biomass of Khaya senegalensis in the Adamawa region, North and Far North of Cameroon.

\section{Materials And Methods}

\section{Study sites}

The study took place in three agro-ecological zones of Cameroon: Sudano-Guinean zone (Adamawa region), Sudano-Sahelian zone (North region) and Sahelian (Far-Norh region). The Adamawa region lies between latitude $6^{\circ}$ and $8^{\circ}$ North and longitude $11^{\circ}$ and $16^{\circ}$ East with an area of $63701 \mathrm{~km}^{2}$ (Awé et al. 2021). The North region is located between latitude $9^{\circ} 18$ 'North and longitude $13^{\circ} 23^{\prime}$ East with an area of $68090 \mathrm{~km}^{2}$ (Awé et al. 2021). The Far North region is located between latitude $11^{\circ} 00^{\prime}$ North and longitude $14^{\circ} 30^{\prime}$ East with an area of $34263 \mathrm{~km}^{2}$ (Awé et al. 2021)(Fig.1).

\section{Criteria for the Selection}

The socio-economic and environmental importance, density, availability, topography and size of Khaya senegalensis (Meliaceae) were the main reasons for the choice of this specie. 


\section{Data collection}

Sampling method was conducted from January 2020 to June 2021. Five sampling plots of $50 \mathrm{~m} \times 50 \mathrm{~m}$ each were established randomly in each of the stands. To conduct this study, the direct method was employed to determine the biomass of each tree. A total of 60 sample trees belonging to Khaya senegalensis were harvested for biomass estimation and allometric equation parameterization in the Adamawa (20 sample trees belonging to Khaya senegalensis), North (20 sample trees belonging to Khaya senegalensis) and Far North (20 sample trees belonging to Khaya senegalensis) region of Cameroon. Selection of each individual tree was based on diameter at breast height $(1.3 \mathrm{~m}$ aboveground). The individuals were grouped into three DBH classes: $0-20 \mathrm{~cm}, 20-40 \mathrm{~cm}, 40-60 \mathrm{~cm}, 60-$ $80 \mathrm{~cm}$. For each sample tree the DBH and total height $(\mathrm{H})$ of the stand trees were first recorded. Trees were felled close to ground level. The trees were selected to ensure a representative distribution of diameter classes within the sampling plots. Individuals were selected on the basis of their availability and the absence of human exploitation (traces of pruning or limping) or disease. Before the trees were felled, the diameters of the individuals with bark were determined using a tape and the total height was determined using a clinometer. The individuals were then cut $5 \mathrm{~cm}$ from the ground using a chainsaw and divided into compartments: the leaves; branches and stem. The stem and large branches were cut into small pieces, and bagged and weighed with a scale in the field.

All 60 trees selected for destructive sampling were excavated for belowground tree component analysis. Once excavated, the main tree components were treated as by Mugasha et al. (2013) as follows: (i) Root crown was cleaned to remove soil and weighed for green weight. (ii) All broken roots (roots not excavated) were measured for top diameter at breakage point on the root crown. Tap root was followed to the point where its diameter was nearly equal to the top diameter of the largest side root, and its weight was included to the weight of root crown. (iii) From each sample tree, 3 main roots (small, medium and big) were selected and traced to minimum diameter of $1 \mathrm{~cm}$. The top diameter and weight of each sample root were measured and recorded. When main roots enter obstacles (stone or another tree) the end point diameter was measured.

A sample from each compartment was taken and dried in an oven for 48 hours, at a temperature of $70^{\circ} \mathrm{C}$ for the leaves and $105^{\circ} \mathrm{C}$ for the stem, branch discs. The water contents of the samples of leaves, branches and trunks will be calculated according to the following formula:

$\mathrm{TE}(\%)=((\mathrm{MH}-\mathrm{MS}) / \mathrm{MS})$ * 100

Where: TE is the water content of the samples in percentage,

$\mathrm{MH}$ and $\mathrm{MS}$ are respectively the wet mass $(\mathrm{Kg})$ and the dry mass $(\mathrm{Kg})$ of the sample. 
From the water content of the samples, the total dry masses of the fractions were calculated as follows:

MST $=100 * \mathrm{MHT} /(100+\mathrm{TE})$

Where: MST is the total dry mass

$\mathrm{MHT}$ is the total wet mass $(\mathrm{Kg})$.

The total dry masses are called biomass and expressed in Kilograms (Kg).

\section{Data Analysis}

Biomass equations using $\mathrm{DBH}$ and $\mathrm{H}$ as the independent variable were developed and were regressed against the leaves, branches, stem, above and below ground Biomss allometric model of individual trees were derived from 20 sample trees in the Adamawa, North and Far North region of Cameroon.

We first used the distance of Cook's residuals to identify outliers of explanatory and response variables (Ganame et al. 2021). We then examined the theoretical relationship between the response variable and the explanatory variables, testing the linear, logarithmic, exponential and power regression models. The response variable is the biomass expressed in $\mathrm{kg}$ and the explanatory variables are the diameter at breast height $(\mathrm{DBH})$ and tree height $(\mathrm{H})$. The best theoretical model retained to develop the equations for predicting the biomass of leaves, branches, stem, AGB and BGB of the tree for this species is the power model:

$$
B=a * D
$$

where $B$ is the biomass, $D$ is the diameter and, $a$ and $b$, the coefficients of regression(Picard et al. 2012; Tchindebe et al. 2019; Ganame et al. 2021).

The following models were considered for estimating Biomass ( $B$, kg dry weight) from $\mathrm{DBH}, \mathrm{H}$ where $a$, $b$ and care coefficients (Picard et al. 2012; Nam et al. 2016; Adam et al. 2018):

$\ln (B)=a+b * \ln (D)$

(Eq.1) 
$\ln (B)=a+b * \ln \left(D^{2}\right)$

(Eq.2)

$\ln (B)=a+b^{*} \ln (D)+c^{*} \ln (H) \quad($ Eq.3)

$\ln (B)=a+b * \ln \left(D^{2} H\right)(E q .4)$

The logarithmic transformation of the data generally leads to a bias in the estimation of Biomass (Chave et al. 2005; Mascaro et al. 2014; Ganame et al. 2021); a correction is therefore necessary and consists in multiplying the estimated Biomass by a correction factor (CF) which is calculated as follows:

$\mathrm{CF}=\exp \left(\mathrm{RSE}^{2} / 2\right)$

CF is a number always greater than 1 (Djomo et al. 2016).

Three criteria were used to measure the robustness and precision of the models in the estimation of above-ground biomass. They are in order of importance:

Adjusted coefficient of determination (Adjusted. $\mathrm{R}^{2}$ ), where STS: Sum of Total Squares and SRS: Sum of Residual Squares.

AIC or Akaike Information Criterion obtained by the following formula:

$A I C=-2 \ln (L)+2 p$

( $L$ "Likelihood" or Probability at which the predicted model is correct to the unknown true and p: Total number of parameters of the model) (Akaike 1981).

RSE or Residual standard error obtained by the following formula:

$\mathrm{RSE}=\ln (\mathrm{AGB}$ obs$)-\ln ($ AGB pred)

where RSE: Residual standard error; AGB obs: Measured above-ground biomass; AGB pred: Predicted above-ground biomass.

The selection of the best allometrics developed for the prediction of the biomass was made on the basis of several statistical parameters. Thus, the lower the residual standard error (RSE), Akaike information criterion (AIC), and the strong adjusted $\mathrm{R}^{2}$, the better the model will be (Picard et al. 2012; Chave et al. 2014). 
The prediction equation for the total biomass of Khaya senegalensis is obtained by combining the best equations of the four compartments of this species in each region. The paired t-test was used to test the significance of the difference between the predicted biomass and the observed biomass. The heteroskedasticity of the selected models was verified by graphically analyzing the trend of estimation errors between predicted values and observed values (Dimobe et al. 2018b; Ganame et al. 2021). The estimation error was calculated using the formula proposed by Mbow et al. (2013):

$\%$ Biais $=($ Predicted biomass - Measured biomass $) /$ Measured biomass $* 100$

The statistical analyzes were carried out with Excel 2020 and R i386 3.1.2 software.

\section{Results}

\section{Measurable Parameters Dendrometric and Pearson's Correlation between Diameters, Height with Biomass}

Between the three regions, the dendrometric parameters (Dbh and $\mathrm{H}$ ) of Khaya senegalensis are more important in the northern region with an average Dbh $(37.32 \mathrm{~cm})$ and an $\mathrm{H}(14.22 \mathrm{~m})$ compared to the other two regions (Table 1). Pearson's correlation shows that in the three regions, the leaf and branch compartments are significantly related to diameter and height, while other components such as stem, AGB and BGB are significantly related only to Diameter but not significant with height ( Table 2).

\section{Modelling allometric equations tests by regions}

Table 3 shows the analysis of variance and confirms that all the regression coefficients of the models tested are statistically significant $(p<0.001)$. These coefficients differ between the biomass of Khaya senegalensis inventoried in the three regions for the same model, with RSE and AIC ranging from $0.308-0.682 \mathrm{~kg}$ and $9.74-18.65 \mathrm{~kg}$ respectively, while their Adj. $\mathrm{R}^{2}$ varies from 0.60-0.98.

\section{Selection of the Best Models by regions}

The Dbh parameter provided a satisfactory model fit for stem biomass, AGB and BGB in all three regions (Table 4). Leaves and branch biomass are best predicted from $D^{2} \times h$ in all three regions (Table 4). These best equations are shown in (Table 4 and Fig.1, Fig.2, Fig.3 and Fig.4) show their adjustments.

\section{Global Modelling allometric equations tests for the three region}

Table 5 shows the analysis of variance confirms that all the regression coefficients of the models tested are statistically significant $(p<0.001)$. These coefficients differ between the biomass of Khaya 
senegalensis inventoried in the three regions for the same model, with RSE and AIC ranging from $0.318-0.533 \mathrm{~kg}$ and $10.63-18.55 \mathrm{~kg}$ respectively, while their $\mathrm{Adj} . \mathrm{R}^{2}$ varies from $0.90-0.98$.

\section{Selection of the Best Global Models and validation for the three regions}

The Dbh parameter provided a satisfactory model fit for stem biomass, AGB and BGB in all three regions (Table 6). Leaves and branch biomass are best predicted from $\mathrm{D}^{2} \times \mathrm{h}$ in all three regions (Table 6). These best equations are shown in Table 6 and Fig. 5 show their adjustments.

The t-test shows that there is no significant difference between the observed values and the predicted values of leaf biomass $(t=0.16$; $p$-value $=0.87)$, branch biomass $(t=0.18 ; p$-value $=0.85)$, stem biomass $(t=0.20 ; p$-value $=0.77), A G B(t=0.29 ; p$ value $=0.73)$, and BGB $(t=0.14 ; p$-value $=0.91)$. The linear regression line between the biomass predicted from the additive model and the observed biomass is almost coincident with the line of equation $\mathrm{y}=\mathrm{x}$ for all biomasses (Fig. 5). These models therefore produce fewer errors in the prediction of the biomass of Khaya senegalensis.

\section{Discussion}

The allometric models developed vary from one compartment to another. This would be linked to the variation in biomass observed between different parts of the species (Ganame et al. 2021). The choice of method and mathematical model for adjusting the parameters must be considered judiciously in estimating the biomass of woody plants (Ganame et al. 2021). The leaf biomass, branch biomass, stem biomass, total biomass (AGB) and belowground biomass (BGB) of individuals were fitted using the linear form of the power model. This mathematical model has been widely used in the literature for the prediction of standing biomass of woody species in Europe (Zianis and Mencuccini 2004) and Africa (Henry et al. 2011; Fayolle et al. 2013; Djomo et al. 2013; Djomo et al. 2016; Mensah et al. 2016a; Xiang et al. 2016; Aabeyir et al. 2020; Ganame et al. 2021). It provides reliable results for several types of biomass prediction; given its elasticity (Bayen 2016; Amani 2016). The sample size was 60 individuals. Indeed, the size of the sample in the development of allometric models is variable in the literature and takes into account the resources and time allocated to the study (Tchindebe et al. 2019). Some allometric biomass equations have been constructed from a limited number of individuals, 26 trees (Guendehou et al. 2012), 20 trees (Mbow et al. 2013), 38 trees (Thiam et al. 2014), 17 trees (Tchindebe et al. 2019), 20 trees (Tchindebe et al. 2020). Others incorporate very few large diameter trees, 1 to $79 \mathrm{~cm}$ in diameter (Djomo et al. 2010).

Indeed, power models generally remain extrapolable with good reliability because they are based on a fractal allometric model which is invariant at all scales (Picard et al. 2012); which explains their wide use in biomass prediction equations for the benefit of logarithmic or polynomial models. The logarithmic 
transformation of the variables carried out in this study remains necessary to reduce the deviations that may exist in a real environment, and to satisfy the conditions of normality and homoscedasticity of the residuals (Chave et al. 2005; Ganame et al. 2021). The allometric models developed with DBH as the sole explanatory variable were the most efficient for the prediction of stem biomass, AGB and BGB of Khaya senegalensis studied.

The precision of the measurement of the explanatory variables is very decisive in the development of allometric equations (Picard et al. 2012). DBH can be easily measured in the field with greater accuracy than other dendrometric parameters. In addition, this variable is always available in the inventory data. Numerous studies have also shown that DBH is the explanatory variable most commonly used for predicting the biomass of different compartments of woody species (Henry et al. 2011; Kuyah et al. 2012; Vahedi et al. 2014;Picard et al. 2015 ; Ganame et al. 2020).

However, the use of this variable alone did not allow an optimal prediction of the biomass of leaves and branches. The incorporation of total height was therefore necessary to improve the quality of prediction of the biomass of leaves and branches of Khaya senegalensis in the regions studied. Some authors believe that the use of DBH alone as an explanatory variable would lead to an increase in the predicted biomass (Chave et al. 2005; Ganame et al. 2020). Others, on the other hand, have shown that the use of DBH alone as an explanatory variable underestimates the prediction of biomass (Alvarez et al. 2012). Furthermore, Xue et al. (2016) and Dong et al. (2018) recommend adding a second variable to solve the uncertainty problem in the biomass assessment by DBH. Previous studies have shown that incorporating height as a second variable improves the prediction performance of elaborate equations ( $\mathrm{Ngomanda}$ et al. 2014; Picard et al. 2015; Mensah et al. 2017; Dimobe et al. 2018a; Dimobe et al. 2018b; Ganame et al. 2020) and has the advantage of increasing the potential of applicability of the equations to different sites (Sawadogo et al. 2010). However, height alone cannot be a good variable for predicting biomass (Oliveras et al. 2013).Biomass prediction models vary according to different tree compartments. The results of these studies are similar to those obtained by Sawadogo et al. (2010); Dimobe et al. (2018a) in Burkina Faso; Henry et al. (2010) in Ghana; Traoré et al. (2018) in Côte d'Ivoire and Ganame et al. (2021) in Burkina Faso who showed a variation in allometric equations depending on the parts of the tree.

The logarithmic $\mathrm{CF}$ is a simple and straightforward statistical tool for eliminating systematic biases produced by converting the estimated logarithmic value to the original untransformed scale (Tchiendebe et al. 2020). However, previous studies indicated that CF are generally small compared to the variation generated by the biomass estimate and therefore can be omitted (Tchiendebe et al. 2020). In the present study, the CF values for all component biomass equations were relatively low. Therefore, our results indicate that few errors were introduced when using the logarithmic transformation to fit allometric equations to biomass data.

\section{Conclusion}


This study shows that the allocation of tree biomass varies depending on the compartment of Khaya senegalensis in three regions of Cameroon. Power-type allometric models fit well to the above-ground and below-ground biomass of the different compartments of Khaya senegalensis. The study also highlighted the specificity of allometric equations according to the parts of the tree. It emerges from these results that the $\mathrm{DBH}$ is the only explanatory variable which makes it possible to predict with satisfaction the biomass of the trunks, AGB and BGB of Khaya senegalensis. These results invalidate our first hypothesis, which states that only the composite variables better predict the biomass of the different compartments of Khaya senegalensis. In contrast, incorporating height as a second explanatory value improves the performance of leaf and branch biomass prediction. All the models developed have a fairly good predictive capacity with regard to the small differences observed between the values observed and those predicted. The established allometric models can be used to estimate the biomass of Khaya senegalensis by component under similar environmental conditions.

\section{Declarations}

\section{Acknowledgements}

We would like to thank all the referees whose contributions have been very important for the improvement of this manuscript.

\section{Conflict of interest statement}

None declared.

\section{References}

Aabeyir R, Adu-Bredu S, Agyare WA, Weir MJC (2020) Allometric models for estimating aboveground biomass in the tropical woodlands of Ghana, West Africa. For Ecos 7:41

Adam SN, Jusob I (2018) Allometric model for predicting aboveground biomass and Carbon stock of Acacia plantations in Sarawak, Malaysia. BioRessources 13(4):7381-7394

AkaikeH (1981) Likelihood of a model and information criteria. J Econ 16:3-14

Awé DV, Noiha NV, Zapfack L (2021) Carbon management for savannah ecosystems in Central Africa: a case study from Cameroon. Inter J Low-Carbon Tech $00: 1-9$

Balima LB, Nacoulma BMI, Bayen P, Dimobe K, Kouamé FN, Thiombiano A (2019) Aboveground biomass allometric equations and distribution of carbon stocks of the African oak (Afzelia africana Sm.) in Burkina Faso. J For Res 1-13 
Bayen P, Bognounou F, Lykke AM, Ouédraogo M, Thiombiano A (2015) The use of biomass production and allometric models to estimate carbon sequestration of Jatropha curcas L. plantations in western Burkina Faso. Env Dev Sus 18:143-156

Chabi A, Lautenbach S, Orekan VOA, Kyei-Baffour N (2016) Allometric models and aboveground biomass stocks of a West African Sudan Savannah watershed in Benin. Carb Bal Manag 16:1-18

Chave J, Rejou MM, Burquez A, Chidumayo E, Colgan MS, Delitti WBC, Duque A, Eid T, Fearnside PM, Goodman RC, Henry M, Martinez Yrizar A, Mugasha WA, Muller-Landau HC, Mencuccini M, Nelson BW, Ngomanda A, Nogueira EM, Ortiz-Malavassi E, Pélissier R, Ploton P, Ryan CM, Saldarriaga JG, Vieilledent $\mathrm{G}$ (2014) Improved allometric models to estimate the aboveground biomass of tropical trees. Glob Change Biol 20:3177-3190

Dimobe K, Mensah S, Goetze D, Ouédraogo A, Kuyah S, Porembski S, Thiombiano A (2018) Aboveground biomass partitioning and additive models for Combretum glutinosum and Terminalia laxiflora in West Africa. Biom Bioenergy 115:151-159

Djomo AN, Chimi CD (2017) Tree allometric equations for estimation of above, below andtotal biomass in a tropical moist forest: Case study with application to remote sensing. For Ecol Manag 391:184-193

Djomo AN, Ibrahima A, Saborowski J, Gravenhorst G (2010) Allometric equations forbiomass estimations in Cameroon and pan moist tropical equations including biomass data from Africa. For Ecol Manag $260: 1873-1885$

Dong L, Zhang LLF (2018) Additive biomass equations based on different Dendrometric variables for two dominant species (Larix gmelini Rupr. and Betula platyphylla Suk.)in natural forests in the Eastern Daxing'an Mountains, Northeast China. Forests 9(5):261. 
Fayolle A, Ngomand A, Mbasi M, Barbier N, Bocko Y, Boyemba F, Couteron P, FontonN, Kamdem N, Katembo J, Kondaoule HJ, Loumeto J, Maïdou HM, Mankou G, Mengui T, Mofack GIl, Moundounga C, Moundounga Q, Nguimbous L, Nchama NN, Obiang D, Asue FOM, Picard N, Rossi V, Senguela YP, Sonké B, Viard L,Yongo OD, Zapfack L, Medjibe VP (2018) A regional allometry for the Congo basin forests based on the largest ever destructive sampling. For Ecol Manag $430: 228-240$

Ganamé M, Bayena P, Ouédraogo I, Balima LH, Thiombiano A (2021) Allometric models for improving aboveground biomass estimates in West African savanna ecosystems. Trees, Forests and People 4 : 100077

Ganamé M, Bayen P, Dimobe K, Ouédraogo I, Thiombiano A (2020) Abovegroundbiomass allocation, additive biomass and carbon sequestration models for Pterocarpus erinaceus Poir. in Burkina Faso. Heliyon 6. https://doi.org/10.1016/j.heliyon.2020.e03805

Goetz SJ, Hansen MC, Houghton RA, Walker W, Laporte N, Busch J (2015) Measurement and monitoring needs, capabilities and potential for addressing reducedemissions from deforestation and forest degradation under Measurement andmonitoring needs, capabilities and potential for addressing reduced emissions from deforestation. Environmental Research Letters 10: 2-25

Henry M, Besnard A, Asante WA, Eshun J, Adu BS, Valentini R (2010) Wood density, phytomass variations within and among trees, and allometric equations in a tropical rainforest of Africa. For Ecol Manag 260(8):1375-1388

Kuyah S, Dietz J, Muthuri C, Jamnadass R, Mwangi P, Coe R, Neufeldt H (2012) Allometric equations for estimating biomass in agricultural landscapes: Il. Belowground biomass. Agri Ecos Envi 158:225-234

Mbow C, Verstraete MM, Sambou B, Diaw AT, Neufeldt H (2013) Allometric models for aboveground biomass in dry savanna trees of the Sudan and Sudan Guinean ecosystems of Southern Senegal. J For Res 19:340-347

Mensah S, Veldtman R, Seifert T (2017) Allometric models for height and aboveground biomass of dominant tree species in South African Mistbelt forests. Southern Forests 79(1):19-30 
Mugasha WA, Eid T, Bollandsas OM, Malimbwi E, Chamshama SAO, Zahabu E, Katani JZ (2013) Allometric models for prediction of above- and belowground biomassof trees in the miombo woodlands of Tanzania. For Ecol Manag 310:87-101

Mugasha WA, Mwakalukwa EE, Luoga E, Malimbwi RE, Zahabu E, Silayo DS (2016) Allometric Models for Estimating Tree Volume and Aboveground Biomass in Lowland Forests of Tanzania. Int J For Res 4:113

Ngomanda A, Obiang NLE, Lebamba J, Mavouroulou QM, Gomat H, Mankou GS, Loumeto J, Iponga DM, Ditsouga FK, Koumba RZ, Bobé KHB, Okouyi CM, Nyangadouma R, Lépengué N, Mbatchi B, Picard N (2014) Site-specific versus pantropical allometric equations: Which option to estimate the biomass of a moist central African forest? For Ecol Manag 312: 1-9

Picard N, Rutishauser E, Ploton P, Ngomanda A, Henry M (2015) Should tree biomass allometry be restricted to power models? For Ecol Manag 353:156-163

Picard N, Saint-André L, Henry M (2012) Manual for building tree volume and biomass allometric equations: from field measurement to prediction. Rome : Food and Agricultural Organization of the United Nations and Montpellier, Centre de Coopération Internationale en Recherche Agronomique pour le Développement, $215 \mathrm{pp}$.

Sawadogo L, Savadogo P, Tiveau D, Dayamba SD, Zida D, Nouvellet Y, Oden PC, Guinko S (2010) Allometric prediction of above-ground biomass of eleven woody treespecies in the Sudanian savanna woodland of West Africa. J For Res 21:475-481

Tchindebe A, Ibrahima A, Tchobsala, Mohamadou LMA (2019) Allometric Equations for Predicting Biomass of Daniellia oliveri (Rolfe) Hutch. \& Dalz. Stands in the Sudano-Guinea Savannahs of Ngaoundere, Cameroon. Ecol Evol Biol 4(2): 15-22

Tchindebe A, Tchobsala, Amadou MLM, Ahmadou H, Adamou I (2020) Species-Specific Allometric Equations for Predicting Biomass of Faidherbia albida (Del.) A. Chev. In the Sudano-sahelian Savannahs of Far-North, Cameroon. J Agri Ecol Res Inter 21(6):33-44 
Thiam S, Sambou B, Mbow C, Guisse A (2014) Élaboration de modèles allométriques d'Acacia Sénégal L. Willd pour l'analyse du carbone ligneux en milieu sahélien : cas de la zone sylvopastorale au Sénégal. Afri Science 10(3):304-315

Traore S, Djomo AN, N'guessan AK, Coulibaly B, Ahoba A, Gnahoua GM, N'guessan EK, Adou Yao CY, N'Dja JK, Guede NZ (2018) Stand structure, allometricequations, biomass and carbon sequestration capacity of Acacia mangium Wild(Mimosaceae) in Cote d'Ivoire. Open J For 8: 42-60

Vahedi AA, Mataji A, Babayi KS, Eshaghi RJ, Hodjati SM, Djomo A (2014) Allometric equations for predicting aboveground biomass of beech-hornbeam stands in the Hyrcanian forests of Iran. $J$ For Science 60: 236-247

Xue Y, Yang Z, Wang X, Lin Z, Li D, Su S (2016) Tree biomass allocation and its model Additivity for Casuarina equisetifolia in a tropical forest of Hainan Island, China. PlosOne 11(3): 1-20

\section{Tables}

Table 1. Measurable Parameters Dendrometric

\begin{tabular}{cccc}
\hline Régions & Item & DBH & H \\
\hline Adamawa & Minimum & 4.76 & 2.98 \\
& maximum & 22.89 & 15.87 \\
\cline { 2 - 4 } North & Mean (sd) & 13.82 & 9.42 \\
\hline & Minimum & 5.76 & 5.58 \\
\cline { 2 - 4 } & maximum & 68.89 & 22.87 \\
\cline { 2 - 4 } Far-North & Mean (sd) & 37.32 & 14.22 \\
\cline { 2 - 4 } & Minimum & 5.32 & 3.51 \\
\cline { 2 - 4 } & maximum & 38.75 & 18.87 \\
\cline { 2 - 4 } & Mean (sd) & 22.03 & 11.19 \\
\hline
\end{tabular}

Dbh: Diameter at Breast height, H: Height.

Table 2. Pearson's Correlation between Diameters, Height with Biomass 


\begin{tabular}{clcc}
\hline \multirow{3}{*}{ Adamawa } & Item & Dbh $(\mathrm{cm})$ & $\mathrm{H}(\mathrm{m})$ \\
\cline { 2 - 4 } & Leaves & $0.86^{* * *}$ & $0.79^{* * *}$ \\
\cline { 2 - 4 } & Branches & $0.90^{* * *}$ & $0.75^{* * *}$ \\
\cline { 2 - 4 } North & stem & $0.76^{* * *}$ & $0.28 \mathrm{~ns}$ \\
\cline { 2 - 4 } & AGB & $0.88^{* * *}$ & $0.32 \mathrm{~ns}$ \\
\cline { 2 - 4 } & BGB & $0.90^{* * *}$ & $0.35 \mathrm{~ns}$ \\
\hline \multirow{3}{*}{ Far-Nom } & Dbh $(\mathrm{cm})$ & $\mathrm{H}(\mathrm{m})$ \\
\cline { 2 - 4 } & Leaves & $0.95^{* * *}$ & $0.88^{* * *}$ \\
\cline { 2 - 4 } & Branches & $0.90^{* * *}$ & $0.73^{* * *}$ \\
\cline { 2 - 4 } & stem & $0.87^{* * *}$ & $0.28 \mathrm{~ns}$ \\
\cline { 2 - 4 } & AGB & $0.88^{* * *}$ & $0.23 \mathrm{~ns}$ \\
\cline { 2 - 4 } & BGB & $0.95^{* * *}$ & $0.35 \mathrm{~ns}$ \\
\cline { 2 - 4 } & Leaves & $0.89^{* * *}$ & $0.68^{* * *}$ \\
\cline { 2 - 4 } & Branches & $0.93^{* * *}$ & $0.70^{* *}$ \\
\cline { 2 - 4 } & stem & $0.85^{* * *}$ & $0.28 \mathrm{~ns}$ \\
\cline { 2 - 4 } & AGB & $0.89^{* * *}$ & $0.38 \mathrm{~ns}$ \\
\cline { 2 - 4 } & BGB & $0.93^{* * *}$ & $0.35 \mathrm{~ns}$ \\
\hline
\end{tabular}

Dbh: Diameter at Breast height, H: Height.

Table 3. Models parameters and performance criteria for biomass estimation 


\begin{tabular}{|c|c|c|c|c|c|c|c|c|c|}
\hline \multirow[t]{2}{*}{ Régions } & \multirow[b]{2}{*}{ Compartments } & \multirow[b]{2}{*}{ Models } & \multicolumn{3}{|c|}{ Regressions coefficients } & \multirow[t]{2}{*}{ Adj. $R^{2}$} & \multirow[t]{2}{*}{ RSE } & \multirow[t]{2}{*}{ AIC } & \multirow[t]{2}{*}{$\mathrm{FC}$} \\
\hline & & & $\mathrm{a}(\mathrm{sd})$ & $\mathrm{b}(\mathrm{sd})$ & $\mathrm{c}(\mathrm{sd})$ & & & & \\
\hline \multirow{20}{*}{ Adamawa } & \multirow[t]{4}{*}{ Leaves } & 4 & $-0.254(0.03) * *$ & $1.304(0.11) * *$ & & 0.83 & 0.545 & 11.65 & 1.16 \\
\hline & & 5 & $0.054(0.00) * * *$ & $-0.011(0.01)^{*}$ & & 0.82 & 0.533 & 12.94 & 1.15 \\
\hline & & 6 & $0.402(0.31)^{* *}$ & $0.119(0.18)^{* *}$ & $0.571(0.12)^{* *}$ & 0.80 & 0.587 & 17.76 & 1.18 \\
\hline & & 7 & $0.321(0.14) * * *$ & $-0.525(0.01) * * *$ & & 0.95 & 0.508 & 10.07 & 1.13 \\
\hline & \multirow[t]{4}{*}{ Branches } & 4 & $-1.043(0.05)^{*}$ & $0.321(0.21)^{* *}$ & & 0.75 & 0.584 & 11.13 & 1.18 \\
\hline & & 5 & $-1.021(0.06)^{* *}$ & $0.752(0.41)^{* *}$ & & 0.70 & 0.503 & 10.24 & 1.13 \\
\hline & & 6 & $-1.053(0.04) * *$ & $0.158(0.01)^{*}$ & $0.882(0.65)^{*}$ & 0.73 & 0.554 & 12.23 & 1.16 \\
\hline & & 7 & $-1.514(0.18) * * *$ & $0.250(0.12) * * *$ & & 0.97 & 0.502 & 10.11 & 1.13 \\
\hline & \multirow[t]{4}{*}{ Stem } & 4 & $2.026(0.21)^{* *}$ & $-1.052(0.11) * * *$ & & 0.94 & 0.601 & 10.10 & 1.19 \\
\hline & & 5 & $-2.167(0.30) * * *$ & $0.815(0.48) * *$ & & 0.69 & 0.654 & 12.11 & 1.23 \\
\hline & & 6 & $-2.103(0.37) * *$ & $0.253(0.15) * * *$ & $0.371(0.26)^{* *}$ & 0.60 & 0.617 & 10.20 & 1.20 \\
\hline & & 7 & $-2.812(0.71) * * *$ & $2.020(0.58)^{* * *}$ & & 0.65 & 0.658 & 14.21 & 1.24 \\
\hline & \multirow[t]{4}{*}{ AGB } & 4 & $1.004(0.47)^{* *}$ & $-0.054(0.00) * * *$ & & 0.98 & 0.403 & 10.08 & 1.08 \\
\hline & & 5 & $-0.302(0.22) * *$ & $2.716(0.29)^{* *}$ & & 0.82 & 0.458 & 10.54 & 1.11 \\
\hline & & 6 & $0.254(0.19)^{*}$ & $-0.029(0.01)^{* *}$ & $0.002(0.00) * * *$ & 0.85 & 0.488 & 10.47 & 1.12 \\
\hline & & 7 & $-0.198(0.10) * *$ & $0.295(0.14) * * *$ & & 0.83 & 0.465 & 10.62 & 1.11 \\
\hline & \multirow[t]{4}{*}{ BGB } & 4 & $-3.009(0.78) * *$ & $0.016(0.00) * * *$ & & 0.96 & 0.511 & 9.74 & 1.13 \\
\hline & & 5 & $2.012(1.01)^{*}$ & $-0.173(0.08) * *$ & & 0.75 & 0.593 & 18.65 & 1.19 \\
\hline & & 6 & $-1.921(0.35)^{* *}$ & $0.033(0.02) * *$ & $0.001(0.00)^{* * *}$ & 0.80 & 0.682 & 10.68 & 1.26 \\
\hline & & 7 & $0.193(0.06)^{* *}$ & $1.102(0.65)^{* * *}$ & & 0.75 & 0.575 & 10.52 & 1.17 \\
\hline \multirow{20}{*}{ North } & \multirow[t]{4}{*}{ Leaves } & 4 & $-0.053(0.02) * *$ & $1.054(0.24)^{* *}$ & & 0.77 & 0.457 & 15.65 & 1.11 \\
\hline & & 5 & $0.014(0.01)^{* *}$ & $-0.211(0.12) * * *$ & & 0.82 & 0.593 & 15.94 & 1.19 \\
\hline & & 6 & $0.002(0.00) * * * *$ & $0.183(0.12)^{*}$ & $0.271(0.18) * *$ & 0.73 & 0.497 & 17.76 & 1.13 \\
\hline & & 7 & $0.121(0.03) * *$ & $-0.325(0.19) * *$ & & 0.95 & 0.431 & 14.87 & 1.09 \\
\hline & \multirow[t]{4}{*}{ Branches } & 4 & $-0.043(0.02) * *$ & $0.581(0.28) * * *$ & & 0.75 & 0.540 & 11.13 & 1.15 \\
\hline & & 5 & $-0.021(0.00)^{* *}$ & $0.452(0.33) *$ & & 0.70 & 0.581 & 10.24 & 1.18 \\
\hline & & 6 & $-0.053(0.01) * *$ & $0.128(0.10)^{*}$ & $0.802(0.40)^{*}$ & 0.73 & 0.538 & 12.23 & 1.15 \\
\hline & & 7 & $-0.574(0.28) *$ & $0.217(0.13) * *$ & & 0.98 & 0.529 & 10.11 & 1.15 \\
\hline & \multirow[t]{4}{*}{ Stem } & 4 & $0.026(0.00)^{* * *}$ & $-1.052(0.23) * * *$ & & 0.94 & 0.413 & 11.10 & 1.08 \\
\hline & & 5 & $-0.167(0.01)^{* *}$ & $0.815(0.41)^{*}$ & & 0.69 & 0.463 & 12.11 & 1.11 \\
\hline & & 6 & $-0.103(0.00) * *$ & $0.253(0.07)^{* *}$ & $0.215(0.03) * *$ & 0.63 & 0.444 & 12.07 & 1.10 \\
\hline & & 7 & $-0.812(0.02) * *$ & $2.020(0.06) * * *$ & & 0.66 & 0.452 & 12.51 & 1.10 \\
\hline & \multirow[t]{4}{*}{ AGB } & 4 & $0.004(0.00) * * *$ & $0.054(0.00)^{*}$ & & 0.95 & 0.522 & 15.05 & 1.14 \\
\hline & & 5 & $-0.302(0.02) * *$ & $0.006(0.00) * * *$ & & 0.83 & 0.545 & 16.54 & 1.16 \\
\hline & & 6 & $0.254(0.07)^{* *}$ & $-0.029(0.01)^{*}$ & $0.002(0.00)^{* * *}$ & 0.81 & 0.580 & 15.74 & 1.18 \\
\hline & & 7 & $-0.198(0.02) * *$ & $0.295(0.07)^{* * *}$ & & 0.80 & 0.576 & 16.54 & 1.18 \\
\hline & BGB & 4 & $-1.301(0.05)^{* * *}$ & $0.116(0.02)^{* *}$ & & 0.90 & 0.312 & 10.45 & 1.04 \\
\hline & & 5 & $0.012(0.00)^{* * *}$ & $-0.073(0.01)^{* *}$ & & 0.72 & 0.319 & 16.04 & 1.05 \\
\hline & & 6 & $-1.921(0.11)^{* *}$ & $0.233(0.18)^{* *}$ & $0.031(0.01)^{* *}$ & 0.70 & 0.320 & 14.92 & 1.05 \\
\hline & & 7 & $0.003(0.01)$ & $1.102(0.01)$ & & 0.77 & 0.315 & 13.87 & 1.05 \\
\hline & Leaves & 4 & $-0.001(0.00) * * *$ & $1.004(0.41)^{* *}$ & & 0.87 & 0.405 & 10.25 & 1.08 \\
\hline Far-North & & 5 & $0.004(0.00)^{* * *}$ & $-0.011(0.00) * * *$ & & 0.82 & 0.343 & 12.33 & 1.06 \\
\hline & & 6 & $-0.002(0.00) * * *$ & $0.103(0.01) * * *$ & $0.003(0.00)^{* * *}$ & 0.83 & 0.407 & 17.36 & 1.08 \\
\hline & & 7 & $0.021(0.01)^{* *}$ & $-0.005(0.00) * * *$ & & 0.95 & 0.308 & 10.18 & 1.04 \\
\hline & Branches & 4 & $-0.043(0.01)^{* *}$ & $0.321(0.11)^{* *}$ & & 0.75 & 0.584 & 11.03 & 1.18 \\
\hline & & 5 & $0.021(0.01)^{*}$ & $0.752(0.22)^{* *}$ & & 0.70 & 0.598 & 10.24 & 1.19 \\
\hline & & 6 & $0.053(0.02)^{* * *}$ & $0.158(0.00)^{* * *}$ & $0.887(0.32)^{*}$ & 0.74 & 0.572 & 12.23 & 1.17 \\
\hline & & 7 & $-0.134(0.04)^{*}$ & $0.250(0.08) * * *$ & & 0.98 & 0.554 & 10.01 & 1.16 \\
\hline
\end{tabular}




\begin{tabular}{|c|c|c|c|c|c|c|c|c|}
\hline \multirow[t]{4}{*}{ Stem } & 4 & $0.026(0.00) * * * *$ & $-1.012(0.61)^{* *}$ & & 0.98 & 0.403 & 10.10 & 1.08 \\
\hline & 5 & $-0.067(0.02) * *$ & $0.015(0.00) * * *$ & & 0.78 & 0.488 & 12.71 & 1.12 \\
\hline & 6 & $-1.003(0.28)^{*}$ & $0.053(0.03) * *$ & $0.371(0.01)^{*}$ & 0.85 & 0.450 & 10.24 & 1.10 \\
\hline & 7 & $-0.012(0.01)^{*}$ & $0.020(0.01)^{* * *}$ & & 0.88 & 0.475 & 12.83 & 1.11 \\
\hline \multirow[t]{4}{*}{ AGB } & 4 & $0.004(0.00)^{* * *}$ & $1.084(0.51)^{* *}$ & & 0.97 & 0.400 & 11.07 & 1.08 \\
\hline & 5 & $-1.302(0.31)^{* *}$ & $0.436(0.16)^{*}$ & & 0.82 & 0.458 & 12.86 & 1.11 \\
\hline & 6 & $0.054(0.01)^{* *}$ & $-0.029(0.00)^{* * *}$ & $0.002(0.01)^{* *}$ & 0.78 & 0.488 & 16.54 & 1.12 \\
\hline & 7 & $-0.043(0.04)^{*}$ & $0.295(0.19) * *$ & & 0.83 & 0.411 & 11.54 & 1.08 \\
\hline \multirow[t]{4}{*}{ BGB } & 4 & $-0.002(0.00) * * *$ & $0.016(0.00)^{* * *}$ & & 0.93 & 0.370 & 13.22 & 1.07 \\
\hline & 5 & $0.012(0.01)^{*}$ & $-0.023(0.01)^{*}$ & & 0.74 & 0.393 & 16.04 & 1.08 \\
\hline & 6 & $-1.921(0.19) * *$ & $0.033(0.02)^{* *}$ & $0.001(0.00) * * *$ & 0.77 & 0.382 & 16.03 & 1.07 \\
\hline & 7 & $0.013(0.01)^{* *}$ & $-0.102(0.01) * *$ & & 0.76 & 0.375 & 15.84 & 1.07 \\
\hline
\end{tabular}

The coefficients at $\mathrm{p}<0.001$ are significantly different from zero; *: Significant, **: Very significant, ***: Highly significant, Standard deviation (sd), AGB: Aboveground biomass, BGB: Belowground biomass, D: Diameter, H: Height, Coefficient of regression model ( $\mathrm{a}, \mathrm{b}$ and $\mathrm{c}$ ), coefficient of determination adjusted (Adj. $\mathrm{R}^{2}$ ), correction factor (CF), residual standard error (RSE)and Akaike information criteria (AIC).

Table 4. Selection of the Best Models by regions

\begin{tabular}{|c|c|c|c|c|}
\hline Régions & Models & Adj. $R^{2}$ & RSE & $\mathrm{AIC}$ \\
\hline \multirow[t]{5}{*}{ Adamawa } & $\ln ($ Bleaves $)=0.321+-0.525^{*} \ln \left(\mathrm{D}^{2} \mathrm{H}\right)$ & 0.95 & 0.508 & 10.07 \\
\hline & $\ln (\mathrm{B}$ branches $)=-1.514+0.250 * \ln (\mathrm{D} \square \mathrm{H})$ & 0.97 & 0.502 & 10.11 \\
\hline & $\ln ($ Bstem $)=2.026-1.052 * \ln (\mathrm{D})$ & 0.94 & 0.601 & 10.10 \\
\hline & $\ln (A G B)=1.004-0.054 * \ln (D)$ & 0.98 & 0.403 & 10.08 \\
\hline & $\ln (B G B)=-3.009+0.016 * \ln (D)$ & 0.96 & 0.511 & 9.74 \\
\hline \multirow[t]{5}{*}{ North } & $\ln ($ Bleaves $)=0.121-0.325 * \ln \left(\mathrm{D}^{2} \mathrm{H}\right)$ & 0.95 & 0.431 & 14.87 \\
\hline & $\ln (\mathrm{B}$ branches $)=-0.574+0.217 * \ln (\mathrm{D} \square \mathrm{H})$ & 0.98 & 0.529 & 10.11 \\
\hline & $\ln ($ Bstem $)=0.026-1.052 * \ln (\mathrm{D})$ & 0.94 & 0.413 & 11.07 \\
\hline & $\ln (\mathrm{AGB})=0.004+0.054 * \ln (\mathrm{D})$ & 0.95 & 0.522 & 15.05 \\
\hline & $\ln (B G B)=-1.301+0.116 * \ln (D)$ & 0.90 & 0.312 & 10.45 \\
\hline \multirow[t]{5}{*}{ Far-North } & $\ln ($ Bleaves $)=0.021-0.005^{*} \ln \left(\mathrm{D}^{2} \mathrm{H}\right)$ & 0.95 & 0.308 & 10.18 \\
\hline & $\ln (\mathrm{B}$ branches $)=-0.134+0.250 * \ln (\mathrm{D} \square \mathrm{H})$ & 0.98 & 0.554 & 10.01 \\
\hline & $\ln ($ Bstem $)=0.026-1.012 * \ln (\mathrm{D})$ & 0.98 & 0.403 & 10.10 \\
\hline & $\ln (\mathrm{AGB})=0.004+1.084 * \ln (\mathrm{D})$ & 0.97 & 0.400 & 11.07 \\
\hline & $\ln (B G B)=-0.002+0.016 * \ln (D)$ & 0.93 & 0.370 & 13.22 \\
\hline
\end{tabular}

B: Biomass, AGB: Aboveground biomass, BGB: Belowground biomass, D: Diameter, H: Height, Coefficient of determination adjusted (Adj. $\mathrm{R}^{2}$ ), residual standard error (RSE)and Akaike information criteria (AIC).

Table 5. Global models parameters and performance criteria for biomass estimation 


\begin{tabular}{|c|c|c|c|c|c|c|c|c|c|}
\hline \multirow[t]{2}{*}{ Three Régions } & \multirow[b]{2}{*}{ Compartments } & \multirow[b]{2}{*}{ Models } & \multicolumn{3}{|c|}{ Regressions coefficients } & \multirow[t]{2}{*}{ Adj. $R^{2}$} & \multirow[t]{2}{*}{ RSE } & \multirow[t]{2}{*}{ AIC } & \multirow[t]{2}{*}{$\mathrm{FC}$} \\
\hline & & & $\mathrm{a}$ & $\mathrm{b}$ & C & & & & \\
\hline \multirow{20}{*}{ Global } & Leaves & 4 & $-0.001(0.00) * * *$ & $0.808(0.12)^{* *}$ & & 0.96 & 0.409 & 15.65 & 1.08 \\
\hline & & 5 & $-0.034(0.01)^{* *}$ & $-0.098(0.03)^{*}$ & & 0.92 & 0.403 & 19.94 & 1.08 \\
\hline & & 6 & $0.002(0.00)^{* * *}$ & $0.804(0.51)^{* *}$ & $0.039(0.01)^{*}$ & 0.93 & 0.407 & 17.76 & 1.08 \\
\hline & & 7 & $0.027(0.01)^{* *}$ & $-0.083(0.03)^{* * *}$ & & 0.98 & 0.318 & 14.87 & 1.05 \\
\hline & Branches & 4 & $-1.098(0.43) * * *$ & $0.028(0.01)^{* *}$ & & 0.95 & 0.533 & 11.34 & 1.15 \\
\hline & & 5 & $1.025(0.63)^{*}$ & $-0.036(0.01)^{* *}$ & & 0.90 & 0.504 & 10.94 & 1.13 \\
\hline & & 6 & $-1.093(0.61)^{* *}$ & $0.105(0.08) * *$ & $-0.006(0.00)^{* * *}$ & 0.93 & 0.511 & 12.23 & 1.13 \\
\hline & & 7 & $0.201(0.01)^{*}$ & $-0.230(0.05)^{* * *}$ & & 0.98 & 0.501 & 10.88 & 1.13 \\
\hline & Stem & 4 & $0.024(0.00)^{* * *}$ & $1.063(0.58)^{*}$ & & 0.97 & 0.323 & 10.63 & 1.05 \\
\hline & & 5 & $-1.077(0.09)^{* *}$ & $0.205(0.11)^{*}$ & & 0.93 & 0.396 & 17.11 & 1.08 \\
\hline & & 6 & $-0.803(0.47)^{*}$ & $0.103(0.05) * *$ & $0.101(0.01)^{* *}$ & 0.95 & 0.358 & 18.20 & 1.06 \\
\hline & & 7 & $-0.312(0.07) * * *$ & $1.028(0.04)^{* *}$ & & 0.94 & 0.383 & 14.76 & 1.07 \\
\hline & AGB & 4 & $0.504(0.02) * *$ & $3.048(0.98)^{*}$ & & 0.98 & 0.454 & 16.07 & 1.10 \\
\hline & & 5 & $-0.002(0.00)^{* * *}$ & $1.903(0.58) *$ & & 0.94 & 0.458 & 18.55 & 1.11 \\
\hline & & 6 & $0.698(0.07) *$ & $-0.034(0.01)^{* * *}$ & $0.102(0.00) * *$ & 0.95 & 0.484 & 16.98 & 1.12 \\
\hline & & 7 & $-0.198(0.05)^{* *}$ & $1.573(0.43)^{*}$ & & 0.96 & 0.464 & 16.50 & 1.11 \\
\hline & BGB & 4 & $-0.109(0.06)^{* * *}$ & $0.306(0.02)^{* *}$ & & 0.98 & 0.472 & 10.80 & 1.11 \\
\hline & & 5 & $3.010(0.25)^{*}$ & $-0.173(0.00) * *$ & & 0.94 & 0.493 & 16.23 & 1.12 \\
\hline & & 6 & $-0.894(0.07) * * *$ & $0.021(0.00)^{* * *}$ & $0.301(0.18) *$ & 0.93 & 0.482 & 16.59 & 1.12 \\
\hline & & 7 & $0.388(0.05)^{* * *}$ & $0.967(0.08) * * *$ & & 0.90 & 0.475 & 16.75 & 1.11 \\
\hline
\end{tabular}

The coefficients at $\mathrm{p}<0.001$ are significantly different from zero; *: Significant, **: Very significant, ***: Highly significant, Standard deviation (sd), AGB: Aboveground biomass, BGB: Belowground biomass, D: Diameter, H: Height, Coefficient of regression model ( $\mathrm{a}, \mathrm{b}$ and $\mathrm{c}$ ), coefficient of determination adjusted (Adj. $\mathrm{R}^{2}$ ), correction factor (CF), residual standard error (RSE) and Akaike information criteria (AIC).

Table 6. Selection of the Best Global Models

\begin{tabular}{lllll}
\hline $\begin{array}{c}\text { Three regions } \\
\text { Global }\end{array}$ & Models & Adj.R & RSE & AIC \\
\cline { 2 - 5 } & $\ln ($ Bleaves $)=0.027-0.083^{*} \ln \left(\mathrm{D}^{2} \mathrm{H}\right)$ & 0.98 & 0.318 & 14.87 \\
\cline { 2 - 5 } & $\ln ($ Bbranches $)=0.201-0.230 * \ln (\mathrm{D} \square \mathrm{H})$ & 0.98 & 0.501 & 10.18 \\
\cline { 2 - 5 } & $\ln ($ Bstem $)=0.024+1.063^{*} \ln (\mathrm{D})$ & 0.97 & 0.323 & 10.63 \\
\cline { 2 - 5 } & $\ln (\mathrm{AGB})=0.504+3.048^{*} \ln (\mathrm{D})$ & 0.98 & 0.454 & 16.07 \\
\cline { 2 - 5 } & $\ln (\mathrm{BGB})=-0.109+0.306 * \ln (\mathrm{D})$ & 0.98 & 0.472 & 10.80 \\
\hline
\end{tabular}

B: Biomass, AGB: Aboveground biomass, BGB: Belowground biomass, D: Diameter, H: Height, Coefficient of determination adjusted (Adj. $\mathrm{R}^{2}$ ), residual standard error (RSE)and Akaike information criteria (AIC).

\section{Figures}




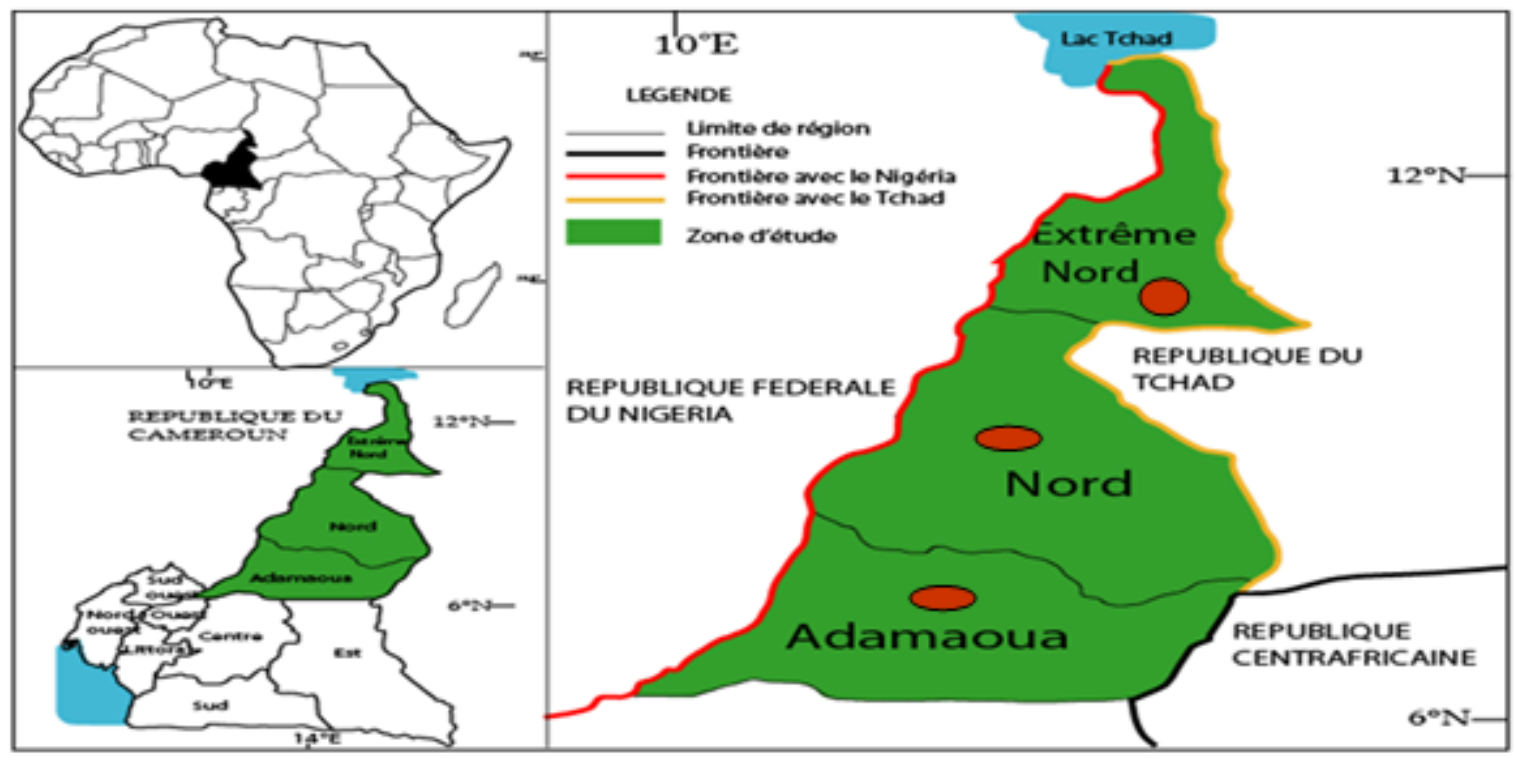

Figure 1

Geographic location of the study area
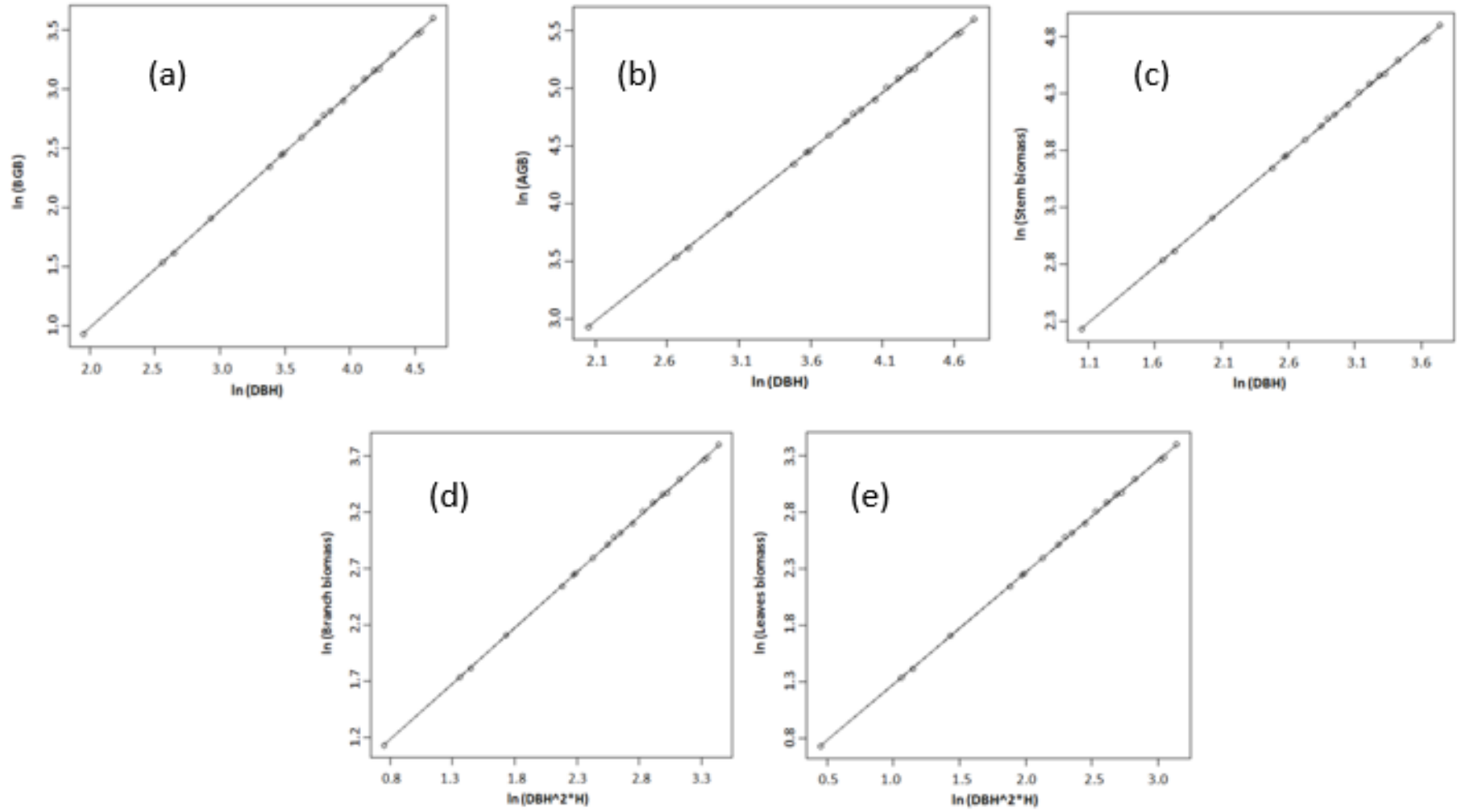

Figure 2

Linear regressions between parameter $(\mathrm{D}$ and $\mathrm{H})$ with leaves biomass $(\mathrm{a})$, branch biomass $(\mathrm{b})$, stem biomass (c), aboveground biomass (d), belowground biomass (e) in the Adamawa region. 

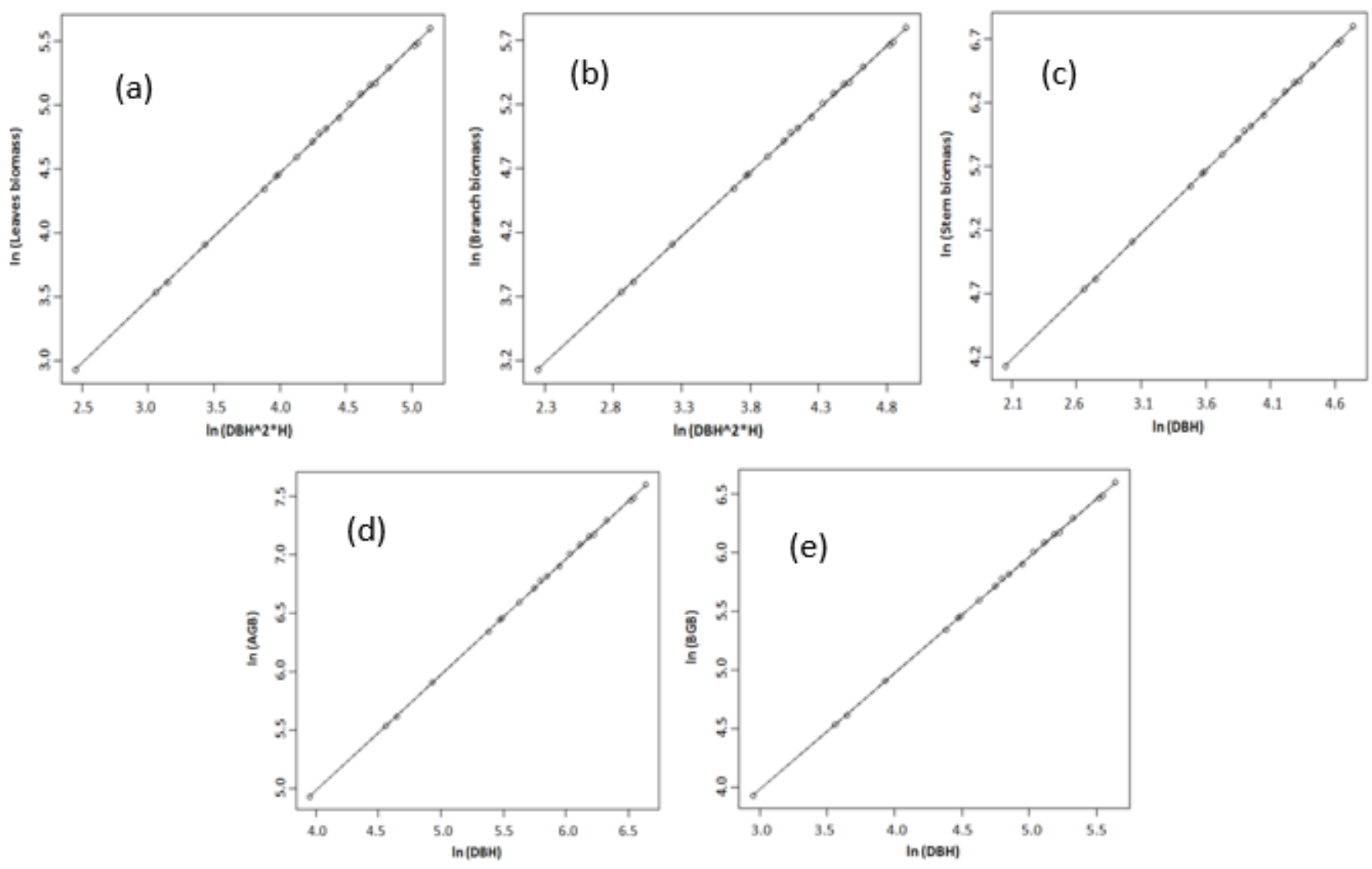

\section{Figure 3}

Linear regressions between parameter $(\mathrm{D}$ and $\mathrm{H})$ with leaves biomass $(\mathrm{a})$, branch biomass $(\mathrm{b})$, stem biomass (c), aboveground biomass (d), belowground biomass (e) in the North region. 

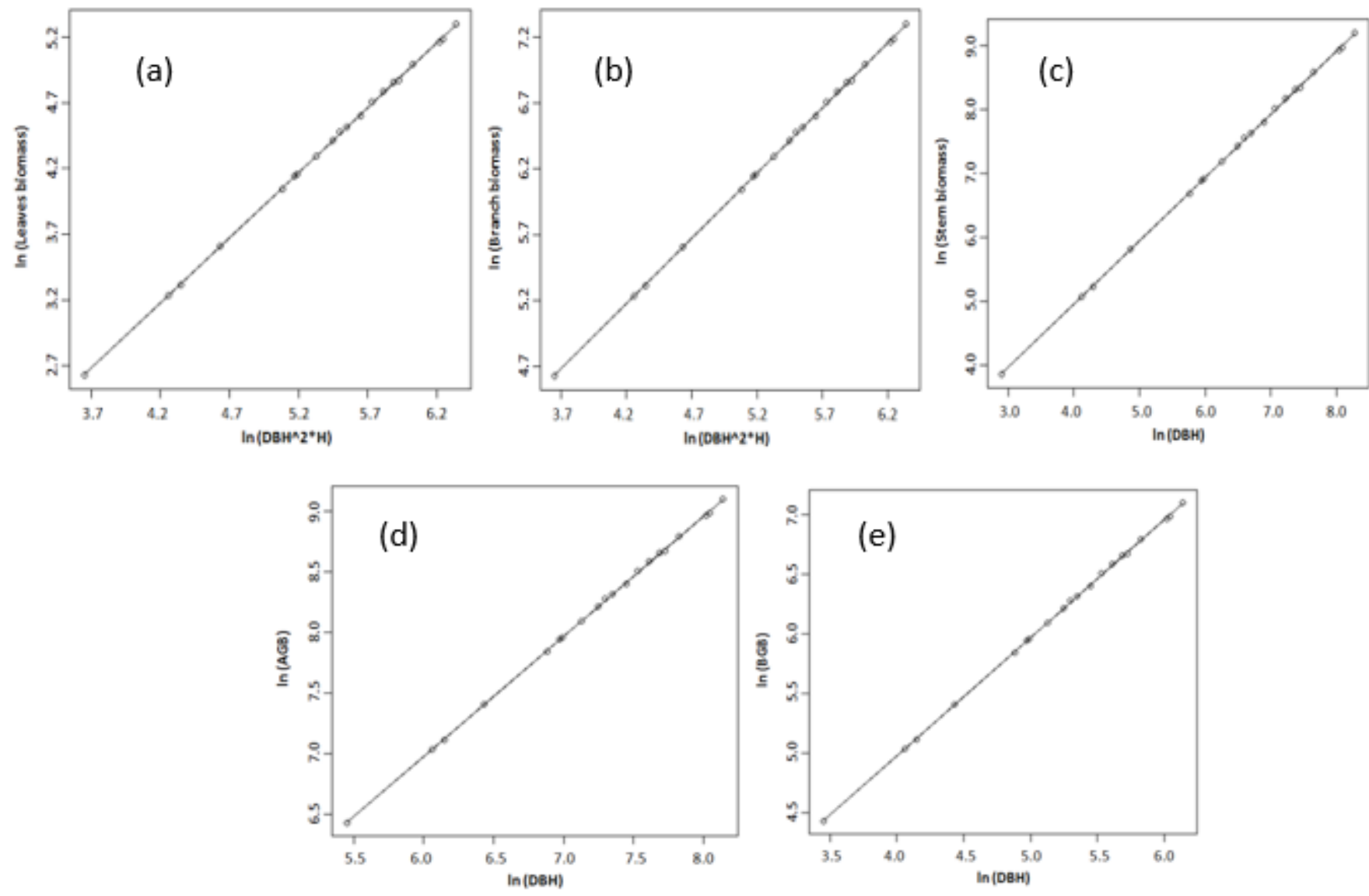

\section{Figure 4}

Linear regressions between parameter $(\mathrm{D}$ and $\mathrm{H})$ with leaves biomass $(\mathrm{a})$, branch biomass $(\mathrm{b})$, stem biomass (c), aboveground biomass (d), belowground biomass (e) in the Far-North region. 

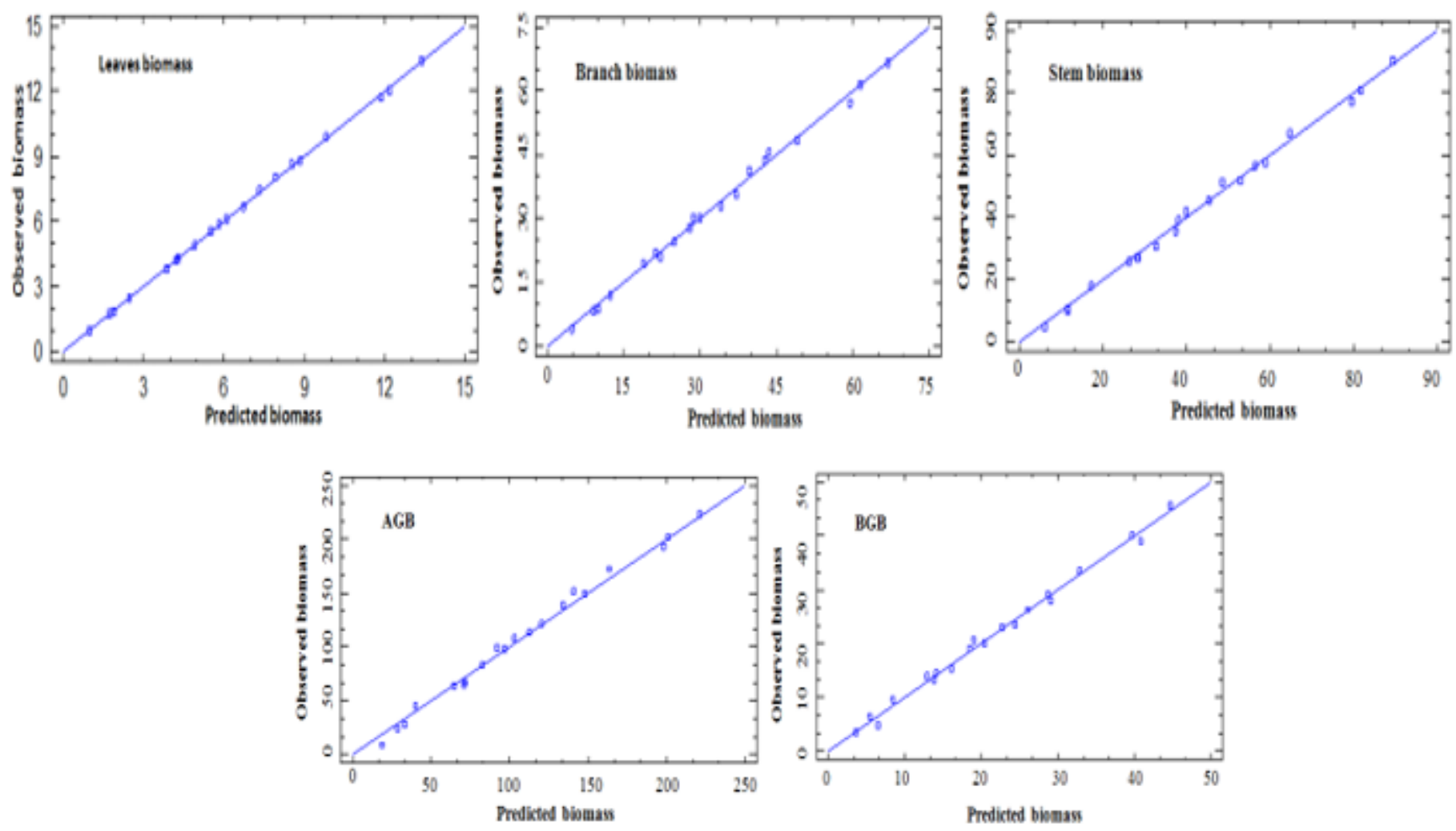

Figure 5

Regression lines between the predicted biomass and the observed biomass of the different compartments of Khaya senegalensis studied. 